emony, that more than $\$ 200$ million had already been raised this academic year from gifts and from among the 250,000 ex-students scattered around the world, those from other universities were torn between envy and admiration. The Peter principle ("To him that hath shall be given...") seemed to be at work again. Although Harvard, even among private universities, has been cleverly imaginative in looking after its money, it clearly benefits from the intellectual quality of its students and from their earning power. Not every institution of higher education can hope to mimic Harvard's success.

Yet many universities will be forced to try in the years ahead. Everywhere, even where universities are notionally the responsibility of central or regional governments, the current recession has made more evident the gap between public subsidy and educational need. And the inadequacy of resources can only, other things being equal, get worse. Where universities are supported by governments, spending on higher education must compete with other forms of welfare spending, themselves destined to increase for demographic and other reasons. In Britain, where tuition is free to undergraduates from Britain and other countries within the European Communities, the London School of Economics (LSE) is now proposing to ask future students to make a contribution towards the cost of their education. Other British universities profess disapproval, on the grounds that it would be better to shame the government into being more generous. But they will be keenly interested to see whether the LSE gets away with its small step towards voluntary privatization.

The dangers are not quite what they seem. Universities strong enough to break with a tradition that tuition is free will, almost by definition, be sensible enough to know that they must preserve the quality of their student intake by means of scholarships, and that the financial benefits that fee-payers bring should not undermine academic standards. The real risk is that governments, impatient as always, will seek to push the successful institutions too quickly along the road to partial independence, and that they will impel others in the same direction when the chances of them making the transition successfully can only be minimal. When at last it seems everywhere to have been recognized that higher education for as many as possible is a public good, that would be folly.

A further problem, nowhere satisfactorily solved, is how students in higher education should be helped to afford the costs they will increasingly be asked to bear. Part of the trouble is that students are often legally adult, but usually innocent of employment. In some places (the United States and Britain, for example), there are schemes for making loans to students. Elsewhere (Australia, for example), graduates pay extra tax. None of these schemes is thoroughly equitable, and there is at least a suspicion that all of them discourage some able students from seeking higher education. But the knowledge that the financing of higher education is a problem common to all reasonably prosperous countries should be at least a comfort; the best hope is that it will lead to common solutions, which of necessity cannot be Harvard's way for all.

\section{Half-tax on US energy}

\section{President Clinton is heading for a fudge on his planned tax on fuels, likely to finish as a tax on gasoline only.}

PRESIDENT Bill Clinton's plan for a better balanced US budget through a blend of higher taxes and reduced spending will be made or broken by the Congress over the next few weeks, but one component of it has already bitten the dust - a general tax on fuel consumption. This tax, the chief source of extra revenue, would have been directly related to the energy content of fossil fuels, for which reason it became known as the 'Btu tax' (after the "British thermal unit" still uniquely used as a unit of energy in the United States).

In the few weeks after the appearance of the budget, Washington's army of special-interest lobbyists had canvassed a host of reasons why the tax would be unfair to their constituents, the poor and the elderly, for example, not to mention international shippers and airlines whose competitiveness would allegedly be impaired. By last week, the president was letting it be known that he cared little how the tax was levied provided that it produced some revenue. The outcome may be an extra federal tax on gasoline, to which there will no doubt be attached a variety of exceptions. That is a cop-out.

On this occasion, there is no reason to suppose that the aversion to the general energy tax has been provoked by the name of the energy unit and by the traditional attitude of the United States towards taxes with British connotations (but there is a case for the United States measuring energy in the units that other people use). Rather, the objections have stemmed from a deep suspicion of taxes that are generally applicable. But Clinton's original purpose was not simply to raise revenue but also to make a start on reducing US emissions of greenhouse gases, for which purpose only a generally applicable tax can mould the pattern of fuel consumption in economical directions. To behave otherwise is to pretend that the effects of molecules of greenhouse gases depend on the purposes for which they were formed as combustion products. But sadly, carbon dioxide molecules from an old people's home are indistinguishable from those from gas-guzzling motor cars.

Ideally, of course, a greenhouse tax should be linked with carbon content. That would imply that natural gas would be less heavily taxed than coal, joule for joule, and that electricity generated by wind-power would not be taxed at all. (In the next few weeks, the farming lobby in Washington can be counted on to fight for exemptions for ethanol produced from sugar, pleading the threat of global warming.) It would have been instructive for us all if the US Congress had been given the task of examining the greenhouse relationships between different fuels; that is the kind of task its committees do well. Indeed, there is a case for starting right away. However much or little revenue the administration squeezes out of the Congress in the next few weeks, the president will be back with a greenhouse tax before very long. 